\title{
The Centralisation of Capital and Monopoly Formation
}

In analysing Kautsky's theoretical conceptions about the centralisation of capital and the formation of monopolistic associations and restrictions of competition, it should be remembered that Kautsky never developed any very systematic theoretical ideas about monopoly capital - or about imperialism. ${ }^{1}$ His formulations are scattered as smaller or larger remarks throughout most of his work, and they are, furthermore, usually connected with rather practical political questions and disputes (the policies of the Social Democrats against the war and restrictive tariffs). Care should be taken in analysing Kautsky's position out of context. There are, however, certain basic ideas and problems that recur throughout his writings. The differences of emphasis caused by the different contexts of discussion should also be kept in mind.

One of the earliest analyses of the formation of monopolies and their effects can be found in The Class Struggle [Das Erfurter Programm]. The new restrictions on competition which became visible and important during the last quarter of the nineteenth century were a result of the centralisation of capital and the decreasing rate of profit. The rate of profit had a tendency to decrease in the long run because the organic composition of capital grew; the share of variable capital became smaller in comparison with the share of constant capital. Following Marx's presentation of the problem, Kautsky argued that the longterm tendency of the rate of profit - and the rate of interest - to decrease could take place simultaneously with an increase in the rate of exploitation. Kautsky remarked that the rate of profit is, furthermore, negatively affected by increasing state expenditure and land rent subtracted from the surplus value produced by industrial capital. The new restrictions of competition at the market are an attempt to compensate the decreasing rate of profit. The monopolistic associations - or the various forms of their existence (cartels, trusts, syndicates, and so on) - are able to price their commodities above their real value by restricting competition and the supply of products. Hence, they are able to get higher gain in the form of extra profit. The formation of big nationwide cartels is the most recent and visible form of this development. ${ }^{2}$

1 See Kraus 1978, pp. 57-8.

2 Kautsky 1910b, pp. 63-4. 
The restrictions of competition and the formation of cartels are made possible by the centralisation of capital. There are fewer and fewer independent firms operating on a certain market. The centralisation of capital has reduced the number of firms on many an important market to a handful of big enterprises co-operating with each other: When cartels are formed, the several concerns that have combined actually form just one concern, quite often under the guidance of a single head. ${ }^{3}$ Such cartels can already be found in certain important fields of production, especially in the production of raw materials (steel and coal cartels).

In his article Imperialist War [Der imperialistische Krieg], Kautsky stated that the motive force behind capitalist production is always the appropriation of extra or maximum profit. Every single capitalist tries to make more profit than his competitors. In general, the extra profit is based on the fact that the firm has a more advantageous position either on the market or in the production process:

Capital was never satisfied with average profits, every capitalist always strove for extra profits. These can be achieved either through a particularly advantageous position on the market, through buying and selling, or through a particularly advantageous position in the production process. ${ }^{4}$

The advantages in the production process are due to more advanced means of production and higher productivity of labour, which make it possible to increase exploitation. As soon as the new methods of production became generalised, there is no extra profit to be appropriated. Such is, however, the case only during free competition. As soon as monopolies or cartels have been introduced and free competition gives way to restrictions of competition the situation changes. Cartellisation and monopoly formation is promoted by the economic policy of the state functioning in the interests of big capital:

The situation changes, however, as soon as monopoly replaces competition. And the time for this comes in the process of capitalist development. Not only does this process centralise capital amongst fewer and fewer hands; employers' associations, joint-stock companies and banks also bring about the centralisation of the management and control of cap-

3 Kautsky 1910b, p. 65 (translation modified BL).

4 Kautsky 1916-17a, p. 475. 
ital far more quickly than they centralise the property of the means of production. Thus there arises in advanced capitalist industrial states the regime of large monopolies and their dominance of [the] state [power]. ${ }^{5}$

As a result, a new method of acquiring extra profits is introduced. The monopolies are able to reach an advantageous position in the market with the help of state power through colonial policy and high import tariffs:

Again, the big capitalists seek to gain a favourable, monopolist position on the market with the help of the state [power]: on the one hand through import tariffs, which weaken foreign competition on the domestic market, relieve the employers' organisations and give them the strength to carry out cut-throat competition [Schleuderkonkurrenz] on the world market. On the other hand, the big capitalists seek to do this through colonial policy - the incorporation of agricultural territories as direct colonies, or as vassal states to the industrial state, and through the monopolisation of these countries as outlets, sources of raw materials and sites of investment for exported capital. ${ }^{6}$

In his writings on imperialism (imperialism was not yet explicitly discussed in the Erfurt Programme), ${ }^{7}$ Kautsky analysed monopolistic extra profits almost exclusively in terms of a new state policy. Imperialism is essentially a new method of securing extra profits for the big cartels and monopolies. The extra profits are due to the restrictions of competition organised by the bourgeois state in the form of restrictive tariffs and colonial policy. According to Kautsky, monopoly profits are thus essentially politically mediated. In this sense, the discussion of monopolies and cartels is closely connected with a discussion of the world market and the orientation of national capitals and states towards changing international competition. Imperialism is a political method of guaranteeing higher profits for the big capitals. ${ }^{8}$

5 Kautsky 1916-17a, p. 477.

6 Ibid.

7 See, however, Kautsky 1910, pp. 83-4.

8 One can agree with Rainer Kraus that Kautsky's theory of the formation of cartels and monopolies was rather unsystematic and fragmentary. According to Kraus, Kautsky explained the formation of monopolies mainly by the strong position of finance capital; consequently, monopolies are sometimes understood to be atavistic phenomena at the time of increasing industrialisation (see Kraus 1978, p. 128). 
In Policy of Trade and the Social Democracy [Handelspolitik und Sozialdemokratie] of 1901, Kautsky stated that the industrial crises in 1873 marked the end of free trade as bourgeois ideal:

Certainly, free competition between the private owners of the means of production remained the best way of reconciling demand and supply, and consumption and production, at least temporarily, and therefore best safeguarding the interests of the consumers. ${ }^{9}$

At the same time as the ideology of free trade was being discredited, the centralisation of capital made the appropriation of extra profits possible in a new way:

If the moral bankruptcy of free competition created the desire to replace it by a private monopoly for the entrepreneurs of individual industries, and to secure for them an exceptional position from which they could extort extra profits using their superior power, then the ongoing centralisation of capital presented the possibility of doing so. ${ }^{10}$

Historically, the cartels developed simultanously with the new system of restrictive tariffs. They represented the specific interests of a small group of capitalists at the cost of the general public [Allgemeinheit]:

The basis of free competition is, as an idea at least, the freedom and equality of buyers and sellers, entrepreneurs and workers. From the outset, the idea of the cartel is to privilege groups of entrepreneurs who bring to bear their superiority both on the market and the shop floor in the most violent and ruthless manner. ${ }^{11}$

If the restrictive tariffs are a political method of increasing the profits of the big capitals organised into cartels, they are essentially a result of the political power of the cartel magnates. However, despite their political power, the cartels are not able to solve all the problems of capital accumulation; on the contrary, they only lead to the sharpening of both the international and national contradictions of capitalism. ${ }^{12}$

\footnotetext{
$9 \quad$ Kautsky 1911b, p. 38.

10 Ibid.

11 Ibid.

12 Kautsky 1911b, p. 94.
} 
Because of the restrictions of competition and production, cartels are faced with the chronic problem of overproduction. Growing exports are the only possible means of solving this problem. The cartels must export their commodities in an ever-increasing amount. There must always be new foreign markets open for their products. On the other hand, the cartels are permanently faced with the problem of cheap raw materials. Both the problems are - at least ostensibly - solved by colonial policy. Colonies offer both a market for the industrial products of cartels and a source of cheap raw materials and foodstuffs. If all the industrial countries follow the interests of the cartels in their foreign economic policy and introduce restrictive tariffs, then naturally the development will out of necessity lead to increasing competition for non-industrial markets and the annexation of colonies. Colonialist competition is the inevitable result of this new economic policy. Consequently, as Kautsky predicted, the conflicts between industrial states become intensified and world war is the logical outcome. ${ }^{13}$ As will be shown later in this study, Kautsky came to modify the results of his analysis. In his later writings, there are alternatives open to capitalism other than war and barbarism or socialism.

13 Kautsky 1911b, pp. 90-4. 